Louisiana State University

LSU Digital Commons

Faculty Publications

Department of Geology and Geophysics

$2-1-2012$

\title{
The geochemistry of upland ponds, Taylor Valley, Antarctica
}

W. Berry Lyons

Byrd Polar and Climate Research Center

Kathleen A. Welch

Byrd Polar and Climate Research Center

Christopher B. Gardner

Byrd Polar and Climate Research Center

Chris Jaros

University of Colorado Boulder

Daryl L. Moorhead

The University of Toledo

See next page for additional authors

Follow this and additional works at: https://digitalcommons.Isu.edu/geo_pubs

\section{Recommended Citation}

Lyons, W., Welch, K., Gardner, C., Jaros, C., Moorhead, D., Knoepfle, J., \& Doran, P. (2012). The geochemistry of upland ponds, Taylor Valley, Antarctica. Antarctic Science, 24 (1), 3-14. https://doi.org/ $10.1017 /$ S0954102011000617

This Article is brought to you for free and open access by the Department of Geology and Geophysics at LSU Digital Commons. It has been accepted for inclusion in Faculty Publications by an authorized administrator of LSU Digital Commons. For more information, please contact ir@lsu.edu. 


\section{Authors}

W. Berry Lyons, Kathleen A. Welch, Christopher B. Gardner, Chris Jaros, Daryl L. Moorhead, Jennifer L. Knoepfle, and Peter T. Doran 


\section{Ariel}

\section{Rapid \# : -6401605}

IP: 129.82.28.195

\section{CALL \#:}

\section{LOCATI ON:}

TYPE:

J OURNAL TITLE: USER J OURNAL TITLE: LHL4CRL CATALOG TITLE:

ARTICLE TITLE: ARTICLE AUTHOR: VOLUME:

ISSUE:

MONTH:

YEAR:

PAGES:

ISSN:

OCLC \#:

CROSS REFERENCE ID: VERIFIED:

\section{Antarctic science / Blackwell Scientific} Publications.

\section{LHL4CRL :: Main Library :: LCSER}

Article CC: CCG

Antarctic science

Antarctic science

Antarctic science / Blackwell Scientific Publications.

The geochemistry of upland ponds, Taylor Valley, Antarctica

Lyons, W. Berry

$$
24
$$

01

2012

3-14

0954-1020

LHL4CRL OCLC \#: 19566001

[TN: 360778][ODYSSEY:206.107.43.25/IAY]

\section{BORROWER: IAY :: Daley Library}

PATRON: 


\title{
The geochemistry of upland ponds, Taylor Valley, Antarctica
}

\author{
W. BERRY LYONS ${ }^{1,2}$, KATHLEEN A. WELCH ${ }^{1}$, CHRISTOPHER B. GARDNER $^{1,2}$, CHRIS JAROS $^{3}$, \\ DARYL L. MOORHEAD ${ }^{4}$, JENNIFER L. KNOEPFLE ${ }^{5}$ and PETER T. DORAN ${ }^{5}$ \\ ${ }^{\prime}$ Byrd Polar Research Center, The Ohio State University, Columbus, OH 43210-1002, USA \\ ${ }^{2}$ School of Earth Sciences, The Ohio State University, Columbus, OH 43210-1002, USA \\ ${ }^{3}$ INSTAAR, University of Colorado, Boulder, CO 80309, USA \\ ${ }_{5}^{4}$ Department of Earth, Ecological and Environmental Sciences, University of Toledo, Toledo, OH 43606, USA \\ ${ }^{5}$ Department of Earth and Environmental Sciences, University of Illinois at Chicago, Chicago, IL 60607, USA \\ lyons.142@osu.edu
}

\begin{abstract}
The McMurdo Dry Valleys of Antarctica are the largest ice-free region on the continent. These valleys contain numerous water bodies that receive seasonal melt from glaciers. For forty years, research emphasis has been placed on the larger water bodies, the permanent ice-covered lakes. We present results from the first study describing the geochemistry of ponds in the higher elevations of Taylor Valley. Unlike the lakes at lower elevations, the landscape on which these ponds lie is among the oldest in Taylor Valley. These upland ponds wax and wane in size depending on the local climatic conditions, and their ionic concentrations and isotopic composition vary annually depending on the amount of meltwater generated and their hydrologic connectivity. This study evaluates the impact of changes in summer climate on the chemistry of these ponds. Although pond chemistry reflects the initial meltwater chemistry, dissolution and chemical weathering within the stream channels, and possibly permafrost fluid input, the primary control is the dilution effect of glacier melt during warmer summers. These processes lead to differences in solute concentrations and ionic ratios between ponds, despite their nearby proximity. The change in size of these ponds over time has important consequences on their geochemical behaviour and potential to provide water and solutes to the subsurface.
\end{abstract}

Received 12 October 2010, accepted 2 June 2011, first published online 23 September 2011

Key words: climate variation, evapoconcentration, McMurdo Dry Valleys, meltwater, solutes

\section{Introduction}

Since the early 1960s, geochemists and limnologists have been intrigued by the biogeochemistry of aquatic systems in the McMurdo Dry Valleys, Antarctica. Studies in "extreme" environments such as these provide insights to system dynamics that are overwhelmed by other processes in more temperate, mesic and biotic-friendly systems. The primary efforts in studying geochemical processes in the McMurdo Dry Valleys (MCM) have been focused on the larger lake systems, especially in Taylor and Wright valleys, where data go back to the early 1960s (Angino et al. 1962). Investigations continued through the 1970s-1980s (e.g. Wharton et al. 1987, Green et al. 1988) with ongoing biogeochemical monitoring since 1993 through the McMurdo Dry Valleys Long-Term Ecological Research (MCM-LTER) project (e.g. Lyons et al. 1998). However, there are many smaller lakes and ponds situated throughout Victoria Land and along the Scott Coast. Many of these aquatic systems have been sampled sporadically over the past 20 years, and much is known about their geochemistry (Torii et al. 1989, Webster et al. 1994, Timperley 1997, Borghini \& Bargagli 2004, Healy et al. 2006, Webster-Brown et al. 2010). These ponds have been referred to in the literature as either "coastal" or "inland", depending on their location and elevation (Borghini \& Bargagli 2004, Wait et al. 2006). However, no published information exists on the geochemistry of the higher elevation, or "upland", ponds in Taylor Valley, which are found at c. $350 \mathrm{~m}$ and $750 \mathrm{~m}$ elevation.

Healy et al. (2006) have demonstrated that the composition of meltwater ponds at elevations above $400 \mathrm{~m}$ in Wright and Victoria valleys (both north of Taylor Valley) reflects two processes: the dissolution of salts in the soils that water flows over and through, and the cryoconcentration of ions via the freeze/thaw process. Working in the Darwin Glacier region, Timperley (1997) has argued that chemical weathering can also add solutes to the ponds, and the differential solubility of salts can affect the geochemistry of cold desert ponds. This differential solubility can be enhanced if a series of ponds are interconnected via downslope drainage (Timperley 1997). For example, during colder years, the upslope ponds may not melt and during the freezing process, certain binary salts are precipitated. During warmer years, the most soluble salts could redissolve and potentially be transported into the down-slope ponds, thereby enriching the down-slope ponds in these ions while 
depleting the upslope ponds (Timperley 1997). Similarly, the differential solubility of binary salts has been demonstrated to occur in hot desert playa systems (Drever \& Smith 1978). Healy et al. (2006) have also shown that chemical weathering is an important process in these upland pond systems, as $\mathrm{Ca}^{2+}$ is much more enriched in the Victoria versus the Wright Valley ponds due to their differences in catchment lithologies. Additionally, the Victoria Valley ponds are more $\mathrm{Cl}^{-}$rich than those in Wright Valley, which have a higher proportion of both $\mathrm{SO}_{4}{ }^{2-}$ and $\mathrm{NO}_{3}{ }^{-}$(Healy et al. 2006). However, all of the inland ponds in Victoria and Wright valleys and in the Darwin Glacier region $\left(\sim 80^{\circ} \mathrm{S}\right)$ are enriched in $\mathrm{NO}_{3}{ }^{-}$compared to the surface waters of the larger MCM lakes. These $\mathrm{NO}_{3}{ }^{-}$enrichments are thought to be due to the higher $\mathrm{NO}_{3}{ }^{-}$salt concentrations observed in the soils in these inland and/or upland elevations as compared to the soils found lower in the valleys (Keys \& Williams 1981, Healy et al. 2006).

Healy et al. (2006) have elegantly demonstrated that as the Wright and Victoria Valley ponds freeze in the winter, $\mathrm{CaSO}_{4} \cdot 2 \mathrm{H}_{2} \mathrm{O}$ (gypsum) then $\mathrm{Na}_{2} \mathrm{SO}_{4}$ salts precipitate from solution in accordance with thermodynamic model prediction. The $\mathrm{Na}_{2} \mathrm{SO}_{4}$ salts redissolve in the summer as the ponds melt. Previous work showed that $\mathrm{CaCO}_{3}$ removal also can occur early on in the evolutionary process in these pond waters (Webster et al. 1994). Apparently, at no time do the Wright and Victoria Valley ponds precipitate nitrate salts, and it is speculated that these very soluble salts can only occur through the subaerial evaporation of residual pond water or through pond ice ablation (Healy et al. 2006). Timperley (1997) has predicted that salt precipitation of relatively insoluble salts such as $\mathrm{CaCO}_{3}$ and $\mathrm{CaSO}_{4} \cdot 2 \mathrm{H}_{2} \mathrm{O}$ will also lead to the fractionation of solutes in ponds that are interconnected, with the down-slope ponds having not only higher TDS, but enrichments in the most soluble salts (i.e. $\mathrm{Cl}^{-}$and $\mathrm{NO}_{3}^{-}$binary salts).

Over a nine year period we sampled a series of ponds in Taylor Valley in order to better determine their chemical composition, sources of both solutes and water, and response to climate variation. We conducted this investigation because our observations in the larger lakes on the floor of Taylor Valley demonstrate important yearly geochemical changes brought about by changes in freshwater input (Welch et al. 2000, Foreman et al. 2004). These variations in hydrologic input are directly related to variations in summer temperatures (Doran et al. 2002). We hypothesize that these ponds may have a more complex response to fluctuating hydrological regimes than the larger lakes because they contain much smaller water volumes. Therefore, variations in water input (through summer glacial melt) or loss (via surface ice sublimation) may have greater relative influence on their geochemical compositions than exhibited by the lakes. However, because these ponds are found at much higher elevations than the lakes, changes in summer temperatures are less extreme and therefore the ponds may not be as greatly impacted by glacial melt as the larger lakes at lower elevations. It has been clearly demonstrated in the Arctic that variation in the chemistry of shallow ponds can be an excellent sentinel of climate variation (Smol \& Douglas 2007). Our initial hypothesis was that changes in hydrologic inflow control the major solute geochemistry of these ponds. This link between summer meteorology and water

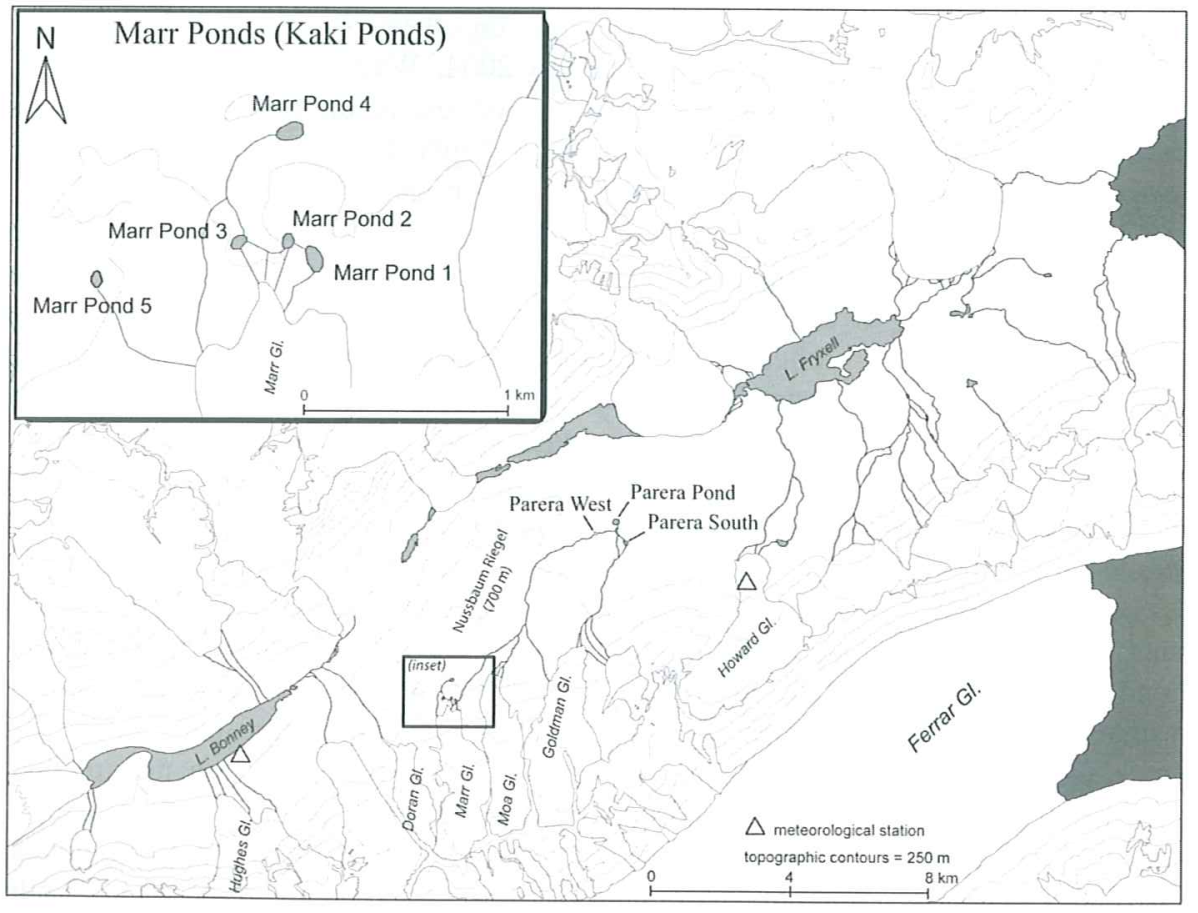

Fig. 1. Map of Taylor Valley showing locations of ponds included in this study. 
balance has been clearly demonstrated in the larger lakes on the valley floor of Taylor Valley (Welch et al. 2000). Because of the smaller size of these ponds, annual variations in water balance should be a major control on solute chemistry. As noted by Timperley (1997) in a conceptual model developed for interconnected or nested Antarctic ponds, increasing temperatures should lead to a transfer of salts, particularly mobile ones such as $\mathrm{Cl}^{-}$, down the flow path into the "terminal" pond.

Although our dataset includes information for many of the ponds throughout Taylor Valley, we focus our discussion in this paper on a series of ponds above $700 \mathrm{~m}$ in elevation above the Nussbaum Riegel, south of Andrews Ridge in south-central Taylor Valley (Fig. 1). We also discuss ponds located c. $4 \mathrm{~km}$ to the east of the Nussbaum Riegel at $350 \mathrm{~m}$. These ponds have been referred to in previous papers (Moorhead et al. 2003, Moorhead 2007) as "upland ponds/wetlands", and we continue this terminology. The flow of liquid water to these features is irregular, with some years having no flow at all (Moorhead et al. 2003, Moorhead 2007). Clearly these fluctuations exert great control on the size and geochemistry of these ponds and Moorhead (2007) has argued that these fluctuations can play a major role in the distribution of organic matter through the valley soils. In this paper we evaluate longer-term (i.e. annual to decadal) changes in the geochemistry of these upland ponds. The work of Healy et al. (2006) clearly demonstrated that the geochemistry of similar McMurdo region ponds vary through an annual cycle. However, until our work, there were limited data from ponds where sampling had been conducted over a multi-year period. Thus, this study reflects one of the few time-series of pond geochemistry in this part of Antarctica. We will compare our geochemical record to the size variation of these ponds over a decade in an attempt to relate climatic and hydrologic changes to our measurements of chemical variations. Finally, we will use a model that computes glacier melt driven by the MCM-LTER temperature records on the Taylor Valley floor to compare the measured pond size with the modelled melt production.

\section{Study area}

The McMurdo Dry Valley's landscape is a mosaic of bedrock, soils, glaciers, ice-covered lakes and ephemeral streams in southern Victoria Land between $77-78^{\circ} \mathrm{S}$ latitude. The climate is considered a polar desert with mean annual temperatures on the valley bottom between -14.8 to $-30.0^{\circ} \mathrm{C}$ (Doran et al. 2002) and precipitation $\sim 5 \mathrm{~cm} \mathrm{a}^{-1}$ (Witherow et al. 2006). The upland ponds under investigation here consist of two separate complexes in the south-central portion of Taylor Valley, one above the Nussbaum Riegel, a $700 \mathrm{~m}$ ridge (Marr ponds), and one c. $4 \mathrm{~km}$ to the east of the Nussbaum Riegel in a topographic depression at $350 \mathrm{~m}$ (Parera ponds). The geology of this region consists of two major series of meta sedimentary rocks, one rich in carbonate and one not, including schists, quartzites and marbles, which are in turn in contact to the west with a granodiorite; these formations are cut by lamprophyric dykes (Haskell et al. 1965). The western portion of Nussbaum Riegel is dotted with recent McMurdo Volcanic basaltic cones. The glacial drift and morainal materials overlying portions of the metamorphic and granodiorite rocks is thought to be derived from the advance of the Taylor Glacier (i.e. East Antarctic Ice Sheet) from the west, and is termed Taylor IV drift. The surface on which the Parera ponds are located is between 1.5 and $2.55 \mathrm{Ka}$ old (Wilch et al. 1993). The surfaces occupied by the Marr ponds at $750 \mathrm{~m}$ a.s.l. investigated here are thought to be the oldest surfaces in Taylor Valley (Marchant \& Denton 1996).

The Nussbaum Riegel serves as a climatic delineation, as the altitude of the glacier equilibrium line (i.e. the separation between mass gain and mass loss), changes abruptly at the Riegel, shifting from $\sim 400 \mathrm{~m}$ on the east side, closer to the coast, to $\sim 1200 \mathrm{~m}$ inland on the west side of the Riegel (Fountain et al. 1999). Local meteorological data from the Nussbaum Riegel are not available. The MCM-LTER program has maintained a series of automated weather stations in the valleys since 1993, with the closest stations being on the Howard Glacier $\sim 8 \mathrm{~km}$ to the east of the Riegel at $473 \mathrm{~m}$ elevation and at Lake Bonney, $\sim 7 \mathrm{~km}$ west

Table I. Pond sizes and hydrologic properties.

\begin{tabular}{|c|c|c|c|c|c|c|}
\hline & $\begin{array}{l}\text { max. measured } \\
\text { area }\left(\mathrm{m}^{2}\right)\end{array}$ & $\begin{array}{l}\text { min. measured } \\
\text { area }\left(\mathrm{m}^{2}\right)\end{array}$ & inflow (sources) & outflow & $\begin{array}{l}\text { approx. stream length } \\
\text { from source glacier }(\mathrm{m})\end{array}$ & $\begin{array}{l}\text { source of sediment } \\
\text { deposition }^{\mathrm{a}}\end{array}$ \\
\hline Marr pond 1 & 11500 & 7000 & Marr Gl. & Marr pond 2 & 200 & $\begin{array}{l}\text { Ice marginal moraine } \\
\text { of Marr Glacier }\end{array}$ \\
\hline Marr pond 2 & 3200 & 1800 & Marr Gl., Marr pond 1 & Marr pond 3 & 250 & \\
\hline Marr pond 3 & 7000 & 3700 & Marr Gl., Marr pond 2 & Marr pond 4 & 200 & \\
\hline Marr pond 4 & 24800 & 9300 & Marr Gl., Marr pond 3 & (Terminal) & 1000 & \\
\hline Parera Pond & 50300 & 15600 & $\begin{array}{l}\text { Marr Gl., Moa Gl., } \\
\text { Goldman Gl., Parera west }\end{array}$ & (Terminal) & $\begin{array}{c}4000 \text { (Goldman Gl.)- } \\
6000 \text { (Moa Gl.) }\end{array}$ & $\begin{array}{l}\text { Pre-LGM Ross Sea } \\
\text { Drift }\end{array}$ \\
\hline Parera south & 4500 & not present & Goldman Gl. & Parera Pond & 3500 & \\
\hline Parera west & 4700 & not present & Marr Gl., Moa Gl., Goldman Gl. & (Terminal) & 5700 & \\
\hline
\end{tabular}

${ }^{a}$ Marchant \& Denton 1996 
of the Reigel at $64 \mathrm{~m}$ elevation (Fig. 1). Since 1993, the mean annual temperatures at these locations are $-17.2^{\circ} \mathrm{C}$ and $-16.9^{\circ} \mathrm{C}$ respectively.

There is a strong spatial gradient of snowfall in Taylor Valley, where less snow falls inland because the Nussbaum Riegel acts as a barrier, blocking low-level clouds that move moisture inland from the ocean (Fountain et al. 2010). Precipitation measured at the nearby Howard Glacier, the closest site to the upland ponds area, ranged from 2-74 mm water equivalent (weq) from 2004-06 (only data available). However, net accumulations can be higher due to wind drifting events $(20-87 \mathrm{~mm}$ weq) (Fountain et al. 2010). Our observation during the period of the MCM-LTER project is that much, if not all, of the spring and summer precipitation is rapidly sublimed and unavailable as runoff, especially at these elevations.

The location of the Taylor Valley upland ponds is shown in Fig. 1. Table I provides a brief description of the ponds and their hydrologic properties. The Marr ponds (unofficial name - officially known as the Kaki Ponds) are at an elevation of $c .750 \mathrm{~m}$ a.s.l. and consist of five ponds. Marr ponds $1,2,3$, and 5 receive direct meltwater input from the Marr Glacier. Marr ponds 1-4 are also connected hydrologically: Pond 1 flows into Pond 2 which flows into Pond 3, which finally flows into Pond 4, the terminal pond. Marr pond 5 is on a bedrock ridge and volcanic cone to the west of the other Marr ponds, and receives melt from the Marr Glacier but is not hydrologically connected to the other ponds.

The Parera Ponds complex is at c. $350 \mathrm{~m}$, and includes associated wetlands and extended hyporheic zones in the down slope areas of the drainage. This pond complex consists of one large pond (Parera Pond also referred to as "Highland Pond" in Moorhead 2007) and two smaller more ephemeral ponds referred to here as Parera west and Parera south (Fig. 1). These ponds receive meltwaters from the Goldman, Moa and the Marr glaciers (Fig. 1). The water in these ponds has extensive interaction with their inflow channels, showing large "wetting zones" or hyporheic interactions many meters away from their primary channels. Water occasionally ponds along the edges of these channels in late December/early January and "wetland" regions can be extensive.

\section{Methods}

Water samples were collected by hand by individuals wearing clean polyethylene gloves into precleaned polyethylene bottles along the edges of the ponds in the melted out moats (Moorhead et al. 2003). Only one sample per pond was collected during each year. There was no attempt to determine whether the ponds were stratified at the time of sampling, and the samples should be considered "surface" samples only. The bottles were rinsed with $18-\mathrm{M} \Omega$ distilled-deionized water (DDW) three times and then filled with DDW for a minimum of $24 \mathrm{hr}$. Major ion and dissolved reactive silicate $\left(\mathrm{H}_{4} \mathrm{SiO}_{4}\right)$ samples were filtered through $0.4 \mu \mathrm{m}$ Nuclepore ${ }^{\mathrm{TM}}$ filters using precleaned plastic filter towers within $24 \mathrm{hr}$ of sample collection, and were stored in clean plastic bags in the dark at $\sim 5^{\circ} \mathrm{C}$ prior to analysis at the Crary Laboratory in McMurdo Station. Major cations and anions were analysed with a DX-120 ion chromatograph using the methods outlined in Welch et al. $(1996,2010)$. The precision of these measurements was $5 \%$ or better. Container blanks of DDW were analysed in every sample run. Alkalinity (i.e. $\mathrm{HCO}_{3}{ }^{-}$) was determined via charge balance difference. We have measured alkalinity by titration in over 900 stream samples in the McMurdo Dry Valleys through the years of the MCM-LTER project and have compared results to alkalinity values computed via charge balance. The mean difference for measured values $>0.50 \mathrm{~m} \mathrm{eq} \mathrm{l}^{-1}$ is $\pm 14 \%$ (calculations were done eliminating two very saline streams draining into the north-west portion of West Lake Bonney). Therefore, we estimate the precision of our alkalinity estimates to be $\pm 14 \%$. Reactive silicate $\left(\mathrm{H}_{4} \mathrm{SiO}_{4}\right)$ was determined using a standard colorimetric molybdate technique on samples that had never been frozen. These analyses took place in the USA. Precision was $10 \%$ or better. Stable isotope samples were analysed on non-filtered samples at INSTAAR, University of Colorado, using the techniques outlined in Gooseff et al. (2006).

Samples from the Marr features were collected during the late portion of the melt season in the 2001/02-2009/10 summer seasons. Goldman Glacier melt features were sampled in 2001-02, 2002-03, and 2005/06-2009/10 summers. Complete ice cover sometimes precluded sample collection from some ponds. The earliest sample collected at the Marr ponds was 23 December in 2004, while the latest collection occurred on 28 January in 2002, though the majority of collections took place between 14-28 January each year. Although only one sample per pond was collected each summer, all the samples from the Marr ponds were collected between 23 December28 January. The Taylor Valley streams usually experience maximum flows between 21 December and the first week of January (www.mcmlter.org). It would have been ideal to collect samples at the same time every year, but due to logistical and other workload constraints, this was not possible. However, with the exception of the first two samples from the Parera Pond complex, all ponds were sampled during the end of, or after, the major valley floor meltwater flows of each summer. The timing of sample collection allows comparability across summers because water input had occurred prior to collecting pond samples each season.

In addition to the geochemical sampling, we have analysed data sources to determine the variation in sizes of these ponds through time (Table II). Data sources include US Geological Survey aerial photography, direct 


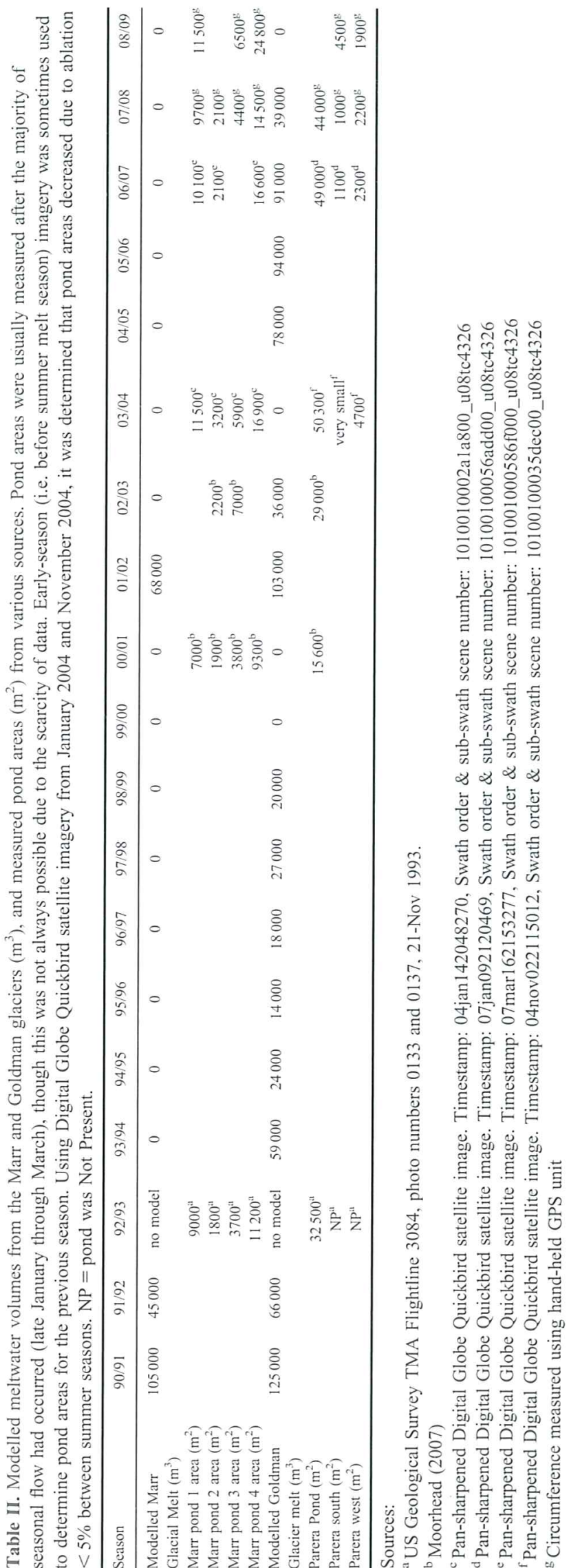

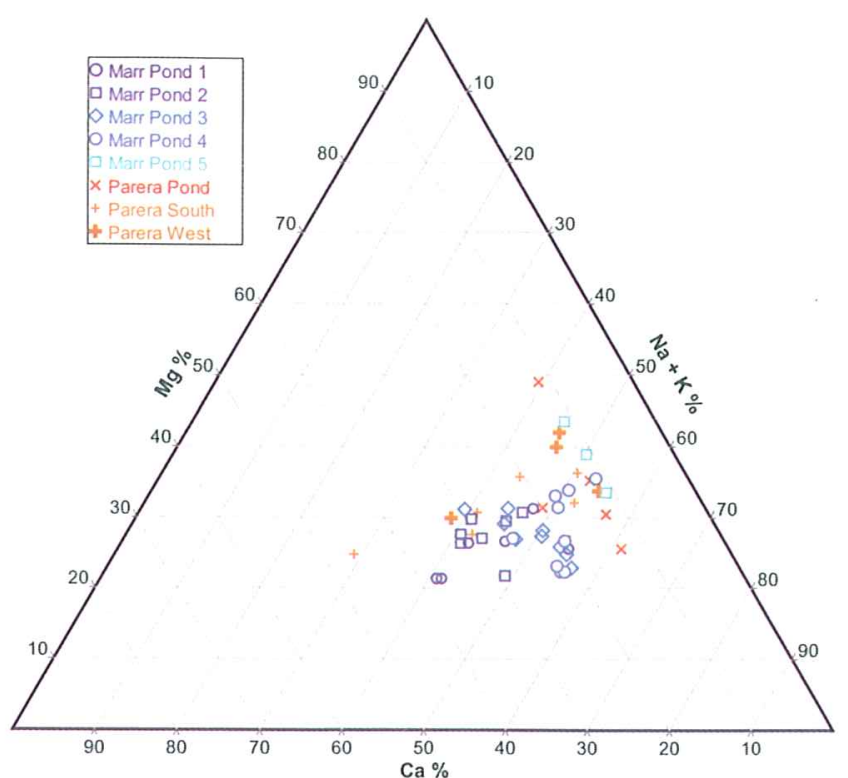

Fig. 2a. Ternary diagram for major cations. $\mathrm{Ca}^{2+}, \mathrm{Mg}^{2+}$ and $\mathrm{Na}^{+}+\mathrm{K}^{+}$are shown as percent by equivalents.

measurements using a hand-held GPS (Moorhead 2007) and Digital Globe Quickbird satellite images.

\section{Results and discussion}

Major ion (both cation and anion) data and stable isotope data of water (where available) for the ponds are tabulated in Appendix A. The 2001-02 summer was abnormally warm and produced a large amount of stream discharge (Foreman et al. 2004), as well as flow features, such as seeps, which had not previously been observed in Taylor Valley (e.g. Lyons et al. 2005). Since 2001-02, stream flows have generally remained substantially lower, with the exception of the 2007-08 season, which was slightly higher than others (www.mcmlter.org) were.

In general, the cation chemistry of the Marr ponds and most of the Parera ponds clusters together on a ternary diagram (Fig. 2a). A few of the Parera Pond samples contain higher relative $\mathrm{Mg}^{2+}$ than the others, with one having $\mathrm{Mg}^{2+}$ as the major cation and much lower $\mathrm{Na}^{+}+\mathrm{K}^{+}$concentrations. The explanation for this is not obvious, although there are abundant cones of the McMurdo volcanics that could be undergoing weathering to produce these different cation variations. The higher $\mathrm{Mg}^{2+}$ concentrations could possibly reflect a higher degree of evaporation history of the pond water at these times, as $\mathrm{Mg}^{2+}$ is concentrated relative to $\mathrm{Ca}^{2+}$ during the evapoconcentration process (Eugster \& Jones 1979).

The Marr pond 5 samples are enriched in $\mathrm{Ca}^{2+}$ compared to the others (Fig. 2a) and closely resemble the cationic composition of the ponds in Victoria Valley as noted by Healy et al. (2006). The Marr pond data represent a transition of compositions from Wright Valley to Victoria Valley cationic concentrations (Healy et al. 2006). 


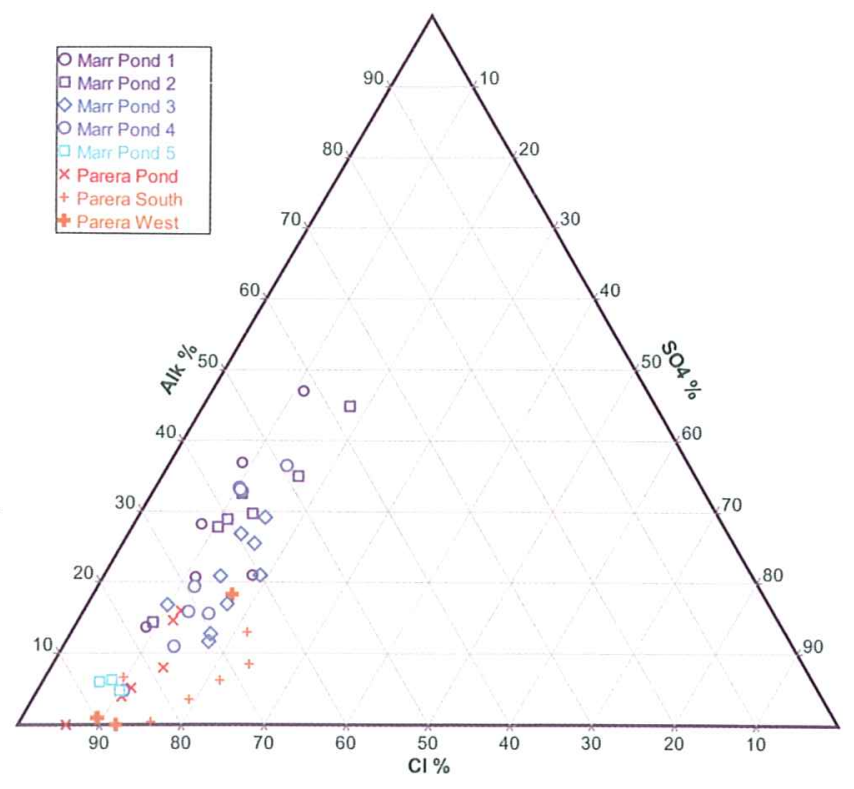

Fig. 2b. Ternary diagrams for major anions. $\mathrm{Cl}^{-}, \mathrm{SO}_{4}{ }^{2-}$ and alkalinity are shown as percent by equivalents.

The anionic diagram (Fig. 2b) shows a wide range of $\mathrm{HCO}_{3}{ }^{-}$and $\mathrm{Cl}^{-}$, but a much smaller range of $\mathrm{SO}_{4}{ }^{2-}$ values. Only three of the Parera Pond samples have $\mathrm{SO}_{4}{ }^{2-}>20 \%$, with relative $\mathrm{Cl}^{-}$concentrations varying between 95 and $\sim 50 \%$. The Marr pond 5 samples contain the highest relative $\mathrm{HCO}_{3}{ }^{-}$concentrations. The $\mathrm{Ca}-\mathrm{Na}-\mathrm{Cl}$ Marr pond 5 waters are very unusual in the MCM region; the Parera

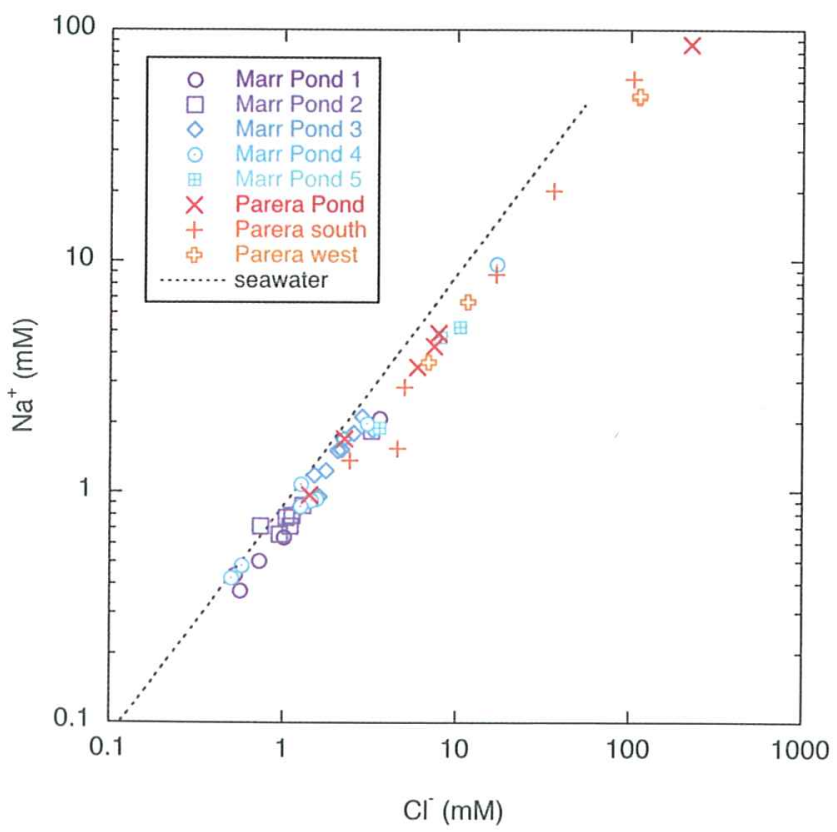

Fig. 3. Sodium versus chloride in millimolar concentrations for the pond samples. The seawater line represents the ionic ratio of $\mathrm{Na}$ to $\mathrm{Cl}$ in seawater.
Pond waters are $\mathrm{Na}-\mathrm{Cl}$ and $\mathrm{Mg}-\mathrm{Cl}$. Clearly this is a very wide diversity of chemical composition within a close proximity. The $\mathrm{Na}-\mathrm{Cl}$ rich waters reflect the primary precipitation signal of the marine aerosol, as the majority of samples have $\mathrm{Na}: \mathrm{Cl}$ slightly less than 1:1 (Fig. 3). The enrichment of $\mathrm{Ca}^{2+}, \mathrm{Mg}^{2+}$ and/or $\mathrm{HCO}_{3}{ }^{-}$clearly suggests that the chemical weathering of alkaline earth-rich minerals within the catchments is a major process even at these low mean annual temperatures. This enrichment may also be due to the dissolution of $\mathrm{CaCO}_{3}$-rich dust introduced by Aeolian processes, especially in the winter. The source of the $\mathrm{CaCO}_{3}$-rich dust is unknown, but it is found on the alpine glaciers in Taylor Valley with some of the highest values on the nearby Howard Glacier (Witherow et al. 2006).

Because $\mathrm{Ca}^{2+}$ and $\mathrm{CO}_{3}{ }^{2-}$ binary salts are the least soluble in these types of environments (Healy et al. 2006), the enrichment of these ions in the pond waters is not due to selective loss of the other major ions in the solution. In the Marr pond 5 region, as noted above, the abundance of McMurdo volcanic rocks must be a major source of solute acquisition via weathering. Unlike previous work in both the Labyrinth ponds in Wright Valley and the ponds in Victoria Valley, the enrichment of $\mathrm{HCO}_{3}{ }^{-}$over $\mathrm{SO}_{4}{ }^{2-}$ makes the Marr pond 5 pond waters unusual. Also unlike the Wright Valley ponds, these Taylor Valley ponds have very low $\mathrm{NO}_{3}{ }^{-}$concentrations (Appendix A), with the highest values being only a few $\mu \mathrm{M}$. Because our samples were collected in December and January and because all these ponds have abundant algal mats associated with them (Moorhead et al. 2003), we speculate that most of the input of $\mathrm{N}$ into these systems is rapidly taken up by the benthic mats. Total $\mathrm{N}$ along the edges of these ponds has been determined to be $\sim 11 \mu \mathrm{M}$ with $\mathrm{C}: \mathrm{N}$ molar ratios of 9:1 (Moorhead et al. 2003).

$\mathrm{Cl}^{-}$concentrations in these ponds range over three orders of magnitude (Fig. 3), demonstrating the significance of evapoconcentration via freezing and sublimation (i.e. water loss) and salt dissolution (i.e. salt gain) as major processes controlling their geochemistry, supporting the earlier work of Torii et al. (1989), Webster et al. (1994), Timperley (1997), Healy et al. (2006) and Wait et al. (2006). Although the $\mathrm{Na}: \mathrm{Cl}$ ratio is similar to seawater, suggesting a marine aerosol source as indicated by Torii et al. (1989) for the Labyrinth ponds in Wright Valley and the upland ponds in Victorian Valley (Healy et al. 2006), most of the ponds are slightly enriched in $\mathrm{Cl}^{-}$relative to seawater (Fig. 3). At $\mathrm{Na}^{+}$concentrations above $2 \mathrm{mM}$, the $\mathrm{Cl}^{-}$enrichment becomes greater, perhaps suggesting loss of $\mathrm{Na}^{+}$via $\mathrm{Na}_{2} \mathrm{SO}_{4}$ precipitation or the dissolution of more soluble $\mathrm{Cl}^{-}$rich salts over time. The highest $\mathrm{Cl}^{-}$and $\mathrm{Na}^{+}$values occur in the lowest elevation pond with the longest flow path: the Parera Pond complex.

The $\mathrm{Ca}: \mathrm{Cl}$ ratio of all the ponds is greater than that of seawater, but approaches the seawater value at the highest $\mathrm{Cl}^{-}$concentrations (Fig. 4). We interpret this to mean that 


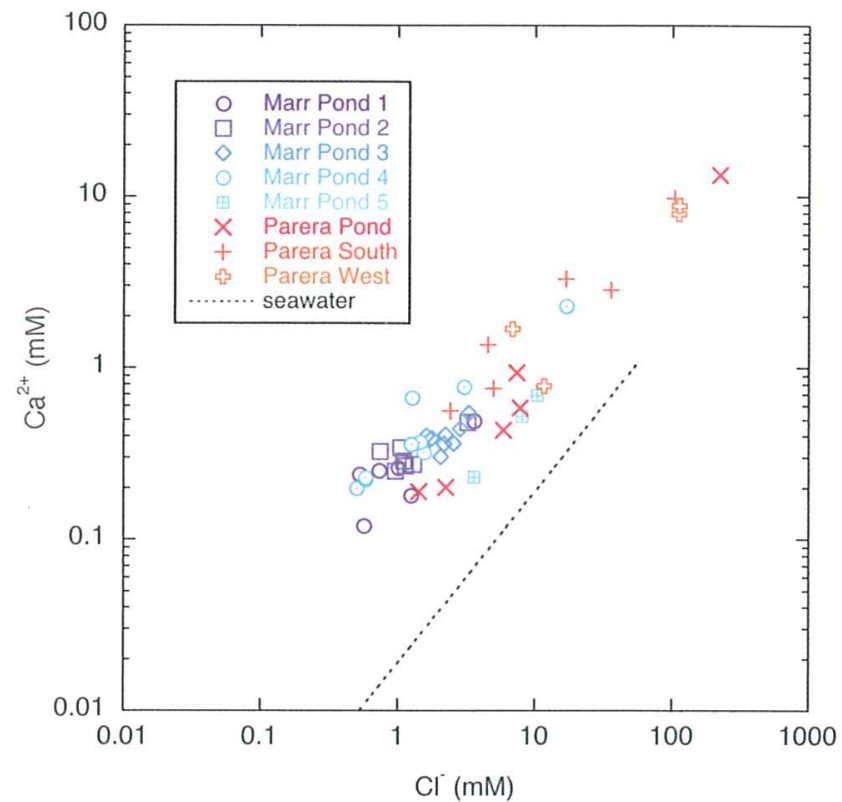

Fig. 4. Calcium versus chloride in millimolar concentrations for the pond samples. The seawater line represents the ionic ratio of $\mathrm{Ca}$ to $\mathrm{Cl}$ in seawater.

$\mathrm{Ca}^{2+}$ is gained through rock/soil weathering (above marine aerosol values) and is lost via $\mathrm{CaCO}_{3}$ precipitation as the pond waters are concentrated via freezing and/or evaporation, as suggested by Webster et al. (1994). The highest $\mathrm{Ca}^{2+}$ enrichment to $\mathrm{Cl}^{-}(\sim 1: 1)$ relative to seawater is in Marr

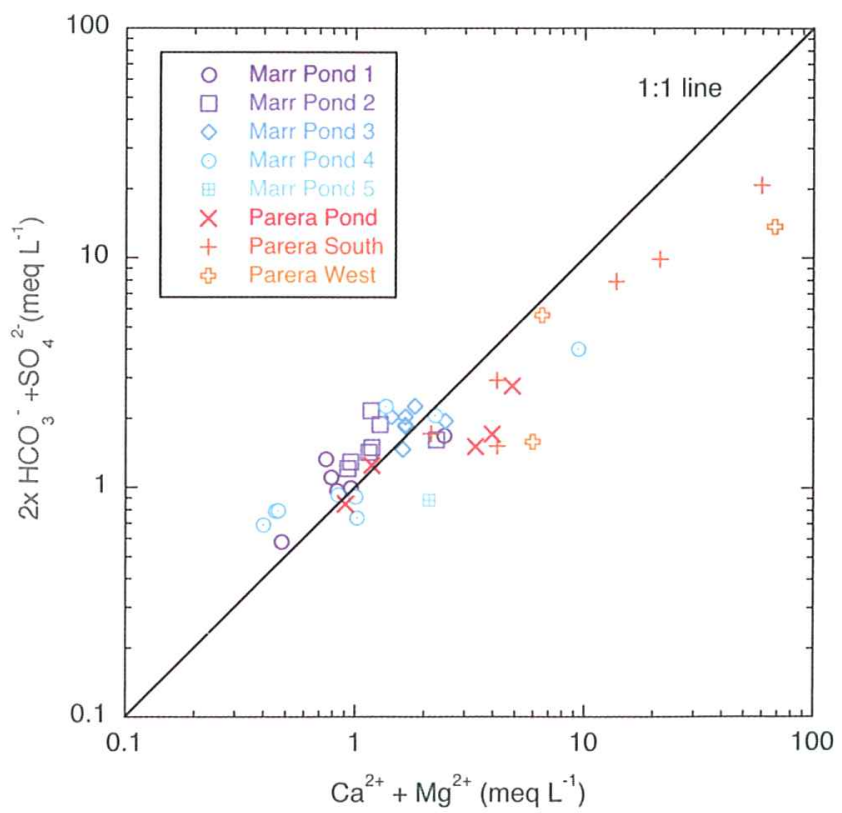

Fig. 5. The sum of bicarbonate and sulphate versus the sum of magnesium and calcium as milliequivalents per litre for pond samples. pond 5 where abundant basalt outcroppings occur and where chemical weathering may be more extensive.

Figure 5 shows the $\mathrm{Mg}^{2+}+\mathrm{Ca}^{2+}$ data plotted vs $2 \times \mathrm{HCO}_{3}{ }^{-}$ (alkalinity) $+\mathrm{SO}_{4}{ }^{2-}$. Points close to the $1: 1$ line reflect either the dissolution of $\mathrm{Mg}+\mathrm{Ca}: \mathrm{CO}_{3}+\mathrm{SO}_{4}$ salts or the initial marine aerosol input (this is particularly true at the lower concentrations). Points with excess $\mathrm{HCO}_{3}+\mathrm{SO}_{4}$ (above 1:1) reflect chemical weathering of minerals and/or dissolution of salts with cations other than $\mathrm{Ca}^{2+}$ or $\mathrm{Mg}^{2+}$, while those data falling below the line indicate samples enriched in $\mathrm{Ca}^{2+}$ and $\mathrm{Mg}^{2+}$ relative to $\mathrm{HCO}_{3}{ }^{-}$and $\mathrm{SO}_{4}{ }^{2-}$. These latter samples may represent what Healy et al. (2006) have termed "suprapermafrost fluids" enriched in $\mathrm{CaCl}_{2}$ brines. These fluids have lost $\mathrm{Na}$ through $\mathrm{Na}_{2} \mathrm{SO}_{4}$ precipitation as the waters are concentrated. It is possible that these few samples do contain a fraction of hypersaline $\mathrm{Ca}-\mathrm{Cl}$ fluid, but the Marr ponds samples also have higher concentrations of $\mathrm{HCO}_{3}{ }^{-}+\mathrm{SO}_{4}{ }^{2-}$, suggesting that they are a mix of this suprapermafrost brine plus slightly evaporated surface waters containing weathering products. Because we have little knowledge of the hydrology and sub-surface water movement in these regions, we cannot definitively determine the sources of water or the solutes in these ponds. Clearly, our data suggest that these ponds are more complex geochemically than many of the other ponds in the McMurdo region. The complexity of these ponds could be a result of their relative elevation, long flow paths and large catchments.

Dissolved $\mathrm{Si}$ concentrations in the ponds range from $0.022-0.123 \mathrm{mM}$ with no geographic pattern (Appendix A). These values are within the range observed in the streams

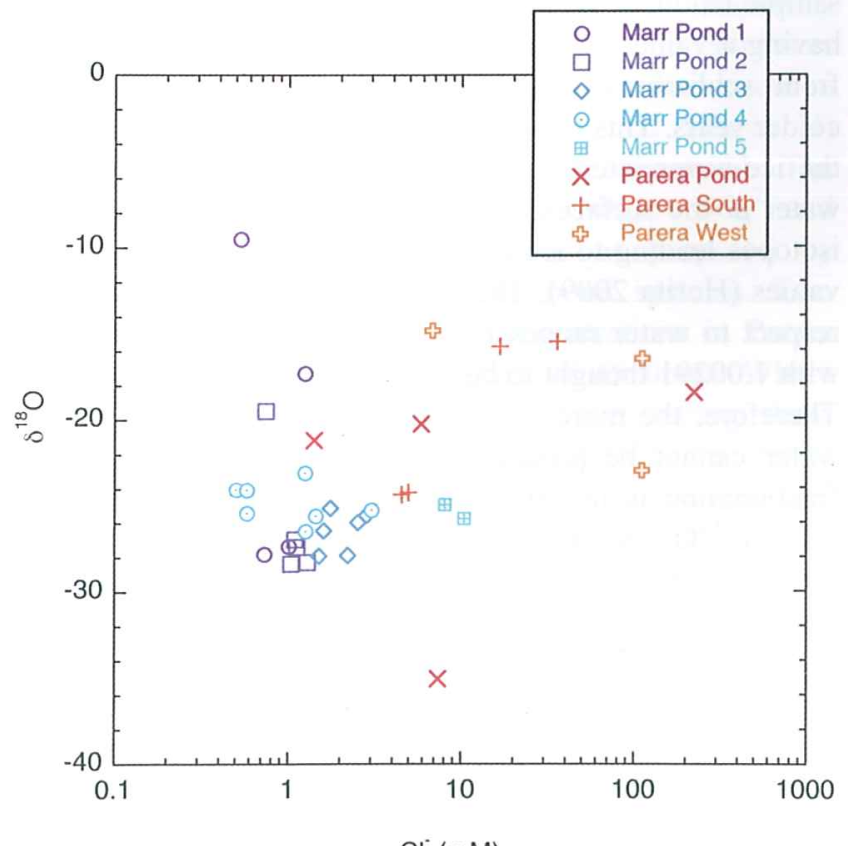

$\mathrm{Cl}^{\circ}(\mathrm{mM})$

Fig. 6. $\delta^{18} \mathrm{O} \%$ versus chloride for pond samples. Not all of the pond samples have been analysed for oxygen isotopic ratio. 
on the Taylor Valley floor (Welch et al. 2010). Because dissolved $\mathrm{Si}$ can only be derived from the chemical weathering of aluminosilicate minerals, it is apparent that even at extremely low mean annual temperatures, chemical weathering is occurring in the stream channels going to and from these ponds.

\section{Role of evaporation in concentrating solutes}

We analysed a number of pond water samples for their stable isotopic composition (Fig. 6). The initial glacier melt should reflect the $\delta^{18} \mathrm{O}$ value of the snow/ice of the glaciers. Moving inland from the ocean in Taylor Valley, the $\delta^{18} \mathrm{O}$ of the precipitation becomes lighter, with Howard Glacier (east of Marr Glacier) having a $\delta^{18} \mathrm{O}$ value of $-27 \%$ and Hughes Glacier (to the west of Marr Glacier) having a value of $-30.8 \%$ (Gooseff et al. 2006). Although we have not analysed any samples from the Marr Glacier, based on our previous work on the glaciers throughout Taylor Valley, the Marr Glacier should have values between -28 and -29\% (Gooseff et al. 2006). A water sample collected in 2004 from a stream flowing directly from the Marr Glacier yielded a $\delta^{18} \mathrm{O}$ value of $-29.2 \%$, suggesting that our $\delta^{18} \mathrm{O}$ isotopic composition estimate for the Marr Glacier melt is appropriate. As water evaporates, the ${ }^{16} \mathrm{O}$ is preferentially lost and the liquid remaining becomes enriched in ${ }^{18} \mathrm{O}$. The freshest pond waters have $\delta^{18} \mathrm{O}$ of $-28.2 \%$ and $-27.2 \%$ (Fig. 6), perhaps suggesting that even these lowest $\mathrm{Cl}^{-}$waters have experienced some degree of evaporation. All but one of the samples above $5 \mathrm{mM} \mathrm{Cl}^{-}$ have $\delta{ }^{18} \mathrm{O}$ more enriched than $-26 \%$, with one Parera Pond sample having a value of $-18.3 \%$ and a Marr pond sample having a value of $-17.3 \%$. Water is lost from these ponds from sublimation of their ice covers, especially during colder years. This loss is replaced by the freeze-on of ice at the ice-water interface. The production of ice from liquid water at the surfaces of these ponds also fractionates the isotopes leading to ice covers with more enriched isotopic values (Horita 2009). The isotopic enrichment of ice with respect to water ranges from $1.00291-1.0048$ for ${ }^{18} \mathrm{O} /{ }^{16} \mathrm{O}$ with 1.00291 thought to be the best estimate (Horita 2009). Therefore, the more enriched stable isotope values of the water cannot be produced from ice development as the fractionation is in the wrong direction. Both evaporative loss of ${ }^{16} \mathrm{O}$ and the sublimative loss of ${ }^{18} \mathrm{O}$ complicate the interpretation of the isotope data. Clearly, many of the samples are greatly enriched in ${ }^{18} \mathrm{O}$ relative to the Marr Glacier melt. These samples indicate evaporative processes have occurred in the ponds or in streams in transit to the ponds, or both. With one exception, the most ${ }^{18} \mathrm{O}$-enriched samples are in the Parera ponds, which are at the lowest elevations (i.e. warmer locations) and have the longest stream lengths (Table I; Fig. 1). Samples with glacier-like $\delta^{18} \mathrm{O}$ signatures but higher dissolved salt concentrations may reflect recent unevaporated glacier melt that has redissolved previously precipitated salt or mixed with "flushed out" preconcentrated salt from the upflow ponds (Timperley 1997). This process has explained similar chemistries in hot desert ecosystems (Drever \& Smith 1978).

\section{Role of climate variation on pond evolution}

The size, chemistry and even existence of these ponds depend primarily on the amount of glacier melt produced during the summer. The MCM-LTER has done extensive work since 1993 to document the linkage between changing meteorological conditions, primarily temperature, glacier melt and stream flow (e.g. McKnight et al. 1999, Ebnet et al. 2005). The geochemistry of the surface waters of the large lakes in Taylor Valley (i.e. lakes Bonney, Fryxell and Hoare) has responded to changes in meltwater inflows. For example, the $\mathrm{Cl}^{-}$concentration in Lake Hoare, the freshest of these lakes, increased by a factor of c. 2 during the low flow years between 1993-94 and 1997-98 (Welch et al. 2000). In addition to glacial melt, substantial melt can occur from multi annual snowpacks and subsurface melting of permafrost during extremely warm years, although these contributions to the overall hydrology of the valley are probably small (Lyons et al. 2005, Harris et al. 2007). Temperature data from the LTER's network of automatic weather stations have been used to model the generation of glacier melt, and these models have been validated using the LTER's stream gauge records (Jaros 2002, Ebnet et al. 2005). We have used the model developed by Jaros (2002) to predict meltwater generation from both the Marr and the Goldman glaciers from the 1990/91-2008/09 seasons (Table II). This model uses temperature data collected at the Taylor Valley floor (Lake Fryxell station) and an adiabatic lapse rate calculation to predict temperatures at the elevations of these glaciers. Although a simple approach, this model has worked very successfully at predicting the flows from the lower elevation glaciers in the eastern portion of Taylor Valley including Commonwealth, Canada and Howard glaciers (Jaros 2002). During this period, according to our model, melt from the Goldman Glacier occurred in all but five years, although flow volume varied by approximately a factor of 9 during the 14 summers when flow did occur. Conversely, for the Marr Glacier, flow occurred only in three summers during this period, according to our model simulations. These summers were the warmest of this period, and only one with substantial melt (i.e. $>1000 \mathrm{~m}^{3}$ ) took place since the establishment of the MCM-LTER (i.e. 2001-02).

In previous work, Moorhead et al. (2003) noted that Marr 3 pond was almost dry and Marr ponds 1, 2 and 4 had extensive algal mat distribution beyond their shorelines and had "thick ice with high albedo" but with melted out margins. During 2000-01, there was stream flow into Marr 2 pond and from the eastern portion of the Marr Glacier, but it did not reach the Parera ponds as it disappeared $50 \mathrm{~m}$ down

obser

Table

$(200$

melt

that

surfa

(Fore

high

areas

is ex

(Dor

$\mathrm{O}$
mea

(Tab

Pon

Pare

Mos

mec

et a

in $\mathrm{s}$

seas

incr

ano

200

afte

and

$\mathrm{Cl}^{-}$ 
down slope (Moorhead et al. 2003). There was also no flow observed between the ponds as normally observed (Fig. 1, Table I). These earlier observations by Moorhead et al. (2003) suggest that our model simulations may underestimate melt from these glaciers into these ponds. There is no doubt that the 2001-02 summer produced extensive melt and surface water flow through both Taylor and Wright valleys (Foreman et al. 2004). This increase in melt also occurred at higher elevations in the valley as shown in the measured pond areas in Table II, and suggests that the hydrology of the valley is extremely sensitive to the short, intense warming events (Doran et al. 2002, Lyons et al. 2005).

Our modelled flows can be compared to the actual measurement of the pond sizes during this time period (Table II). In general, the Marr ponds and the large Parera Pond are relatively small from 1992/93-2000/01, and Parera south and Parera west were not present in 1992-93. Most of the summers in this period were very cool with medium to very low flows in the valley streams (Doran et al. 2002). From 2000/01-2002/03, the ponds increased in size. The 2001-02 summer was an extremely high flow season (deemed the "flood year") when the valley lakes increased greatly in volume (Foreman et al. 2004). There was another increase in size in the large Parera Pond during 2003-04, with only slight but significant fluctuations in size after this time. The measured $\mathrm{Cl}^{-}$concentrations in Marr pond 1 and Marr pond 2 reflect the pond sizes at least generally. $\mathrm{Cl}^{-}$concentrations decrease from 2001/02-2002/03, increase

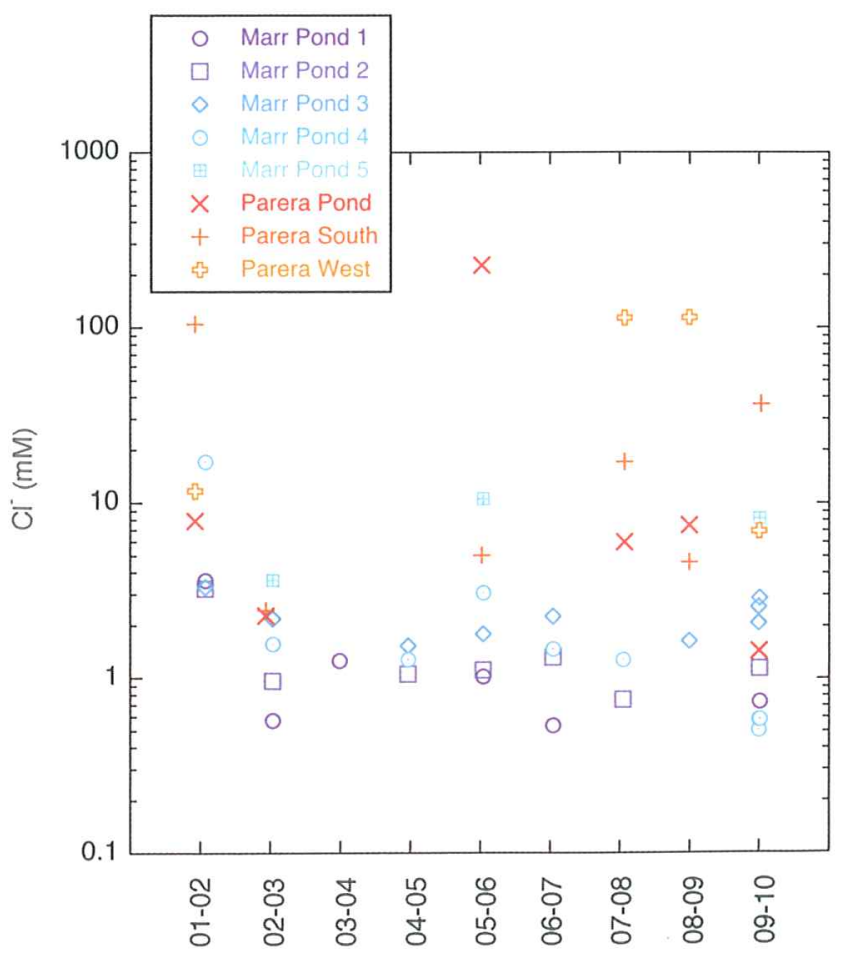

Fig. 7. Chloride concentrations for pond samples plotted versus time. in 2003-04, change little during 2005-06 with a slight decrease in 2006-07 and increases in 2008-09 and 2009-10 (Table II, Fig. 7). In general, variations over this period fit the picture of our knowledge of austral summer temperature variations and the subsequent hydrologic response on the Taylor Valley floor (www.mcmlter.org). There are years when all the Marr ponds and the Parera Pond complex have similar $\mathrm{Cl}^{-}$values (2009-10, 2001-02, 2002-03), and years when the two groups of ponds vary greatly in their $\mathrm{Cl}^{-}$concentrations (2007-08 and 2008-09). In 2002-03, it appears that the Parera system was diluted while the Marr system was also diluted, but the concentrations between Marr ponds varied by almost an order of magnitude. This difference in the Marr ponds' $\mathrm{Cl}^{-}$concentration may be due to lack of sufficient water to "flush" the system (this is similar to the fractionation of soluble salts as proposed in the Timperley (1997) model), or the preferential loss of ice-cover and more enhanced evaporative loss in some of the ponds. The lowest $\mathrm{Cl}^{-}$concentrations were in the uppermost ponds (Marr pond 1 and Marr pond 2) suggesting $\mathrm{Cl}^{-}$was flushed from these ponds downstream into the lower elevation ponds. These data demonstrate that depending on the year, the amount of flow and surface solute concentrations can vary by at least an order of magnitude.

Our original hypothesis was that during "warm" summers when abundant melt is produced from the high elevation glaciers in Taylor Valley such as the Marr and Goldman, the upper set of nested ponds would "flush" salt that was previously concentrated during cooler summers to the terminal pond. Between 2003-04 and 2006-07, Parera Pond was at its largest area and in January 2006 it also had the highest measured solute concentrations $\left(\mathrm{Cl}^{-}=225 \mathrm{mM}\right)$. This suggests that the high flow event in 2001-02 and perhaps another in 2002-03 (Table II) transported large amounts of salt into the pond. The anion composition is dominated by $\mathrm{Cl}^{-}$with low $\mathrm{SO}_{4}{ }^{2-}$ and extremely low $\mathrm{HCO}^{-}$concentrations as proposed by Timperley (1997) for flow-through pond systems. Two years after the maximum solute concentrations in Parera Pond, the $\mathrm{Cl}^{-}$decreased by a factor of 45 times. Where had all this salt gone? We propose that during these accumulations of salt, the terminal ponds (such as Parera Pond) act similar to a "recharge playa" in warm, arid regions of the world. The brackish water accumulated by the flush of meltwater through the upstream pond is lost through sinkage at the bottom of the pond. We also propose that this salt water could flow down-slope at the bottom of the active layer (i.e. top of the permafrost) and become a potential liquid water source lower in the valley. Recent work by Levy et al. (in press) suggests that "water tracks" found in the Lake Hoare region could originate from similar processes. Solute transport by this mechanism may play an important role in transporting both salt and water in the lower valley soils (Levy et al. in press). 


\section{Conclusions}

We have made single surface water measurements in a series of "upland" ponds (elevations $350 \mathrm{~m}$ and $750 \mathrm{~m}$ ) above the Taylor Valley floor in the McMurdo Dry Valleys region of Antarctica. These measurements have been made at least once per year from 2000-2010. Even though these ponds are spatially close, their geochemistrys are diverse, ranging from Na-rich to Ca-rich and $\mathrm{Cl}$-rich to $\mathrm{HCO}_{3}$-rich in a small area. The ponds respond to summer temperature variations, with more meltwater, and hence chemical dilution, occurring during the warmest summers. Variations in summer melt input affects both the bulk chemical concentrations of these ponds and their stable isotopic composition. "Terminal" ponds in a nested pond sequence like the Marr and Parera complex may play an important role in the discharge of water and solutes into the subsurface.

\section{Acknowledgements}

This work was supported by NSF grants - OPP ANT0423595 and OPP-9813061. We thank our MCM-LTER colleagues Diane McKnight, Diana Wall, John Priscu and Andrew Fountain for their intellectual input and insights. We greatly appreciate the help of Paul Morin and Spencer Niebuhr, AGIC, University of Minnesota, for providing satellite images in a very timely manner. We also thank Joe Levy for discussions regarding subsurface water/salt flow in Taylor Valley. We thank J. Gudding, A. Jacobs, L. Miller, L. Michaud and other MCM-LTER personnel for help in sample collection. We thank B. Vaughn at INSTAAR, University of Colorado, for the stable isotope analysis. We are extremely grateful to two anonymous reviewers whose comments and criticisms greatly improved the original manuscript. The senior author thanks Prof J. Laybourn-Parry and the School of Physical Sciences and Geography for their hospitality as the first draft of this paper was completed at Keele University on a Royal Society Travel Fellowship grant to JLP and WBL.

\section{References}

Angino, E.E., Armitage, K.B. \& Tash, J.C. 1962. Chemical stratification in Lake Fryxell, Victoria Land, Antarctica. Science, 138, 34-36.

Borghini, F. \& BARGAGLI, R. 2004. Changes of major ion concentrations in melting snow and terrestrial waters from northern Victoria Land, Antarctica. Antarctic Science, 16, 107-115.

Doran, P.T., McKay, C.P., Clow, G.D., Dana, G.L., Fountain, A.G., Nylen, T. \& Lyons, W.B. 2002. Valley floor climate observations from the McMurdo Dry Valleys, Antarctica, 1986-2000. Journal of Geophysical Research, 107, 4772.

Drever, J.I. \& Smith, C.L. 1978. Cyclic wetting and drying of the soil zone as an influence on the chemistry of ground water in arid terrains. American Journal of Science, 278, 1448-1454.

Ebnet, A.F., Fountain, A.G. \& Nylen, T.H. 2005. An index model of stream flow at below freezing-temperatures in Taylor Valley, Antarctica. Annals of Glaciology, 40, 76-82.
Eugster, H.P. \& Jones, B.F. 1979. Behavior of major solutes during closed-basin brine evolution. American Journal of Science, 279, 609-631.

Foreman, C.M., Wolf, C.F. \& Priscu, J.C. 2004. Impact of episodic warming events on the physical, chemical and biological relationships of lakes in the McMurdo Dry Valleys, Antarctica. Aquatic Geochemistry, 10, 239-268.

Fountain, A.G., Nylen, T.H., Monaghan, A., Basagic, H.J. \& Bromwich, D. 2010. Snow in the McMurdo Dry Valleys, Antarctica. International Journal of Climatology, 30, 633-642.

Fountain, A.G., Lyons, W.B., Burkins, M.B., Dana, G.L., Doran, P.T., Lewis, K.J., McKnight, D.M., Moorhead, D., Parsons, A.N., Priscu, J.C., Wall, D.H., Wharton, R.A. JR \& Virginia, R.A. 1999. Physical controls on the Taylor Valley ecosystem, Antarctica. BioScience, 49, 961-971.

Gooseff, M.N., Lyons, W.B., McKnight, D.M., Vaughn, B.H., Fountain, A.G. \& Dowling, C. 2006. A stable isotopic investigation of a polar desert hydrologic system, McMurdo Dry Valleys, Antarctica. Arctic, Antarctic, and Alpine Research, 38, 60-71.

Green, W.J., Angle, M.P. \& Chave, K.E. 1988. The geochemistry of Antarctic streams and their role in the evolution of four lakes in the McMurdo Dry Valleys. Geochimica et Cosmochimica Acta, 52, $1265-1274$.

Harris, K., Carey, A.E., Welch, K.A., Lyons, W.B. \& Fountain, A.G. 2007. Solute and isotope geochemistry of near-surface ice melt flows in Taylor Valley, Antarctica. Geological Society of America Bulletin, 199, $548-555$.

Haskell, T.R., Kennett, J.P., Prebble, W.M., Smith, G. \& Willis, I.A.G. 1965. The geology of the middle and lower Taylor Valley of south Victoria Land, Antarctica. Transactions of the Royal Society of New Zealand, Geography, 2, 169-186.

Healy, M., Webster-Brown, J.G., Brown, K.L. \& Lane, V. 2006. Chemistry and stratification of Antarctic meltwater ponds II: inland ponds of the McMurdo Dry Valleys, Victoria Land. Antarctic Science, 18, 525-533.

Horita, J. 2009. Isotopic evolution of saline lakes in the low-latitude and Polar regions. Aquatic Geochemistry, 15, 43-70.

JAROS, C.L. 2002. Climatic controls on interamual variation in streamflow in Fryxell Basin, Taylor Valley, Antarctica. Msc thesis, University of Colorado, 91 pp.

Keys, J.R. \& Williams, K. 1981. Origin of crystalline cold desert salts in the McMurdo Region, Antarctica. Geochimica et Cosmochimica Acta, 45, 2299-2309.

Levy, J.S., Fountain, A.G., Gooseff, M.N., Welch, K.A. \& Lyons, W.B. In press. Water tracks and permafrost in Taylor Valley, Antarctica: Extensive and shallow groundwater connectivity in a cold desert ecosystem. Geological Society of America Bulletin.

Lyons, W.B., Welch, K.A., Neumann, K., Moorhead, D. \& McKnight, D.M. 1998. Geochemical linkages among glaciers, streams and lakes within the Taylor Valley, Antarctica. Antarctic Research Series, 72, 77-92.

Lyons, W.B., Welch, K.A., Carey, A.E., Doran, P.T., Wall, D.H., Virginia, R.A., Fountain, A.G., Csatho, B. \& Tremper, C. 2005. Groundwater seeps in Taylor Valley, Antarctica: an example of a subsurface melt event. Annals of Glaciology, 40, 200-206.

Marchant, D.R. \& Denton, G.H. 1996. Miocene and Pliocene paleoclimate of the Dry Valleys region, southern Victoria Land: a geomorphological approach. Marine Micropaleontology, 27, 253-271.

McKnight, D.M., Niyogi, D.K., Alger, A.S., Bomblies, A., Conovitz, P.A. \& TAte, C.M. 1999. Dry Valleys streams in Antarctica: ecosystems waiting for water. Bioscience, 49, 985-995.

Moorhead, D.L. 2007. Mesoscale dynamics of ephemeral wetlands in the Antarctic Dry Valleys: implications to production and distribution of organic matter. Ecosystems, 10, 87-95.

Moorhead, D.L., Barrett, J.E., Virginia, R.A., Wall, D.W. \& PorazinsKa, D. 2003. Organic matter and soil biota of upland wetlands in Taylor Valley, Antarctica. Polar Biology, 26, 567-576. 
Smol, J.P. \& Douglas, M.S.V. 2007. Crossing the final ecological threshold in high Arctic ponds. Proceedings of the National Academy of Sciences, 104, 12395-12397.

Timperley, M.H. 1997. A simple temperature-based model for the chemistry of melt-water ponds in the Darwin Glacier area, 80 degrees S. In Lyons, W.B., Howard-Williams, C. \& Hawes, I., eds. Ecosystem processes in Antarctic ice-free landscapes. Rotterdam: Balkema, 197-206.

Tori, T., Nakaya, S., Matsubaya, O., Matsumoto, G.I., Masuda, N., Kawano, T. \& Murayama, H. 1989. Chemical characteristics of pond waters in the Labyrinth of southern Victoria Land, Antarctica. Hydrobiologia, 172, 255-264.

Wait, B.R., Webster-Brown, J.G., Brown, K.L., Healy, M. \& Hawes, I. 2006. Chemistry and stratification of Antarctic metwater ponds I: coastal ponds near Bratina Island, McMurdo Ice Shelf. Antarctic Science, 18, 515-524.

Webster, J.G., Brown, K.L. \& Vincent, W.F. 1994. Geochemical processes affecting meltwater chemistry and the formation of saline ponds in the Victoria Valley and Bull Pass region, Antarctica. Hydrobiologia, 281, 171-186.

Webster-Brown, J., Gall, M., Gibson, J., Wood, S. \& Hawes, I. 2010. The biogeochemistry of meltwater habitats in the Darwin Glacier region $\left(80^{\circ} \mathrm{S}\right)$, Victoria Land, Antaretica. Antarctic Science, 22, 646-661.
Welch, K.A., Neumann, K., McKnight, D.M., Fountain, A.G. \& Lyons, W.B. 2000. Chemistry and lake dynamics of the Taylor Valley lakes, Antarctica: the importance of long-term monitoring. In Davison, W., Howard-Williams, C. \& Broady, P., eds. Antarctic ecosystems: models for wider ecological understanding. Christchurch: Caxton Press, 282-287.

Welch, K.A., Lyons, W.B., Graham, E., Neumann, K., Thomas, J.M. \& MiKeselL, D. 1996. The determination of major element chemistry in terrestrial waters from Antarctica using ion chromatography. Journal of Chromatography, A739, 257-263.

Welch, K.A., Lyons, W.B., Whisner, C., Gardner, C.B., Gooseff, M.N., McKnight, D.M. \& Priscu, J.C. 2010. Spatial variations in the geochemistry of glacial meltwater streams in Taylor Valley, Antarctica. Antarctic Science, 22, 662-672.

Wharton, R.A., McKay, C.P., Mancinelli, R.L. \& Simmons, G.M. 1987. Perennial N-2 supersaturation in an Antarctic lake. Nature, 325, 343-345.

Wilch, T.I., Denton, G.H., Lux, D.R. \& McIntosh, W.C. 1993. Limited Pliocene glacier extent and surface uplift in middle Taylor Valley, Antarctica. Geographiska Annaler, 75A, 331-351.

Witherow, R.A., Bertler, N.A.N., Welch, K.A., Lyons, W.B., Mayewski, P.A., Sneed, S.B., Nylen, T., Handley, M.J. \& Fountain, A. 2006. The aeolian flux of calcium, chloride and nitrate to the MeMurdo Dry Valleys landscape: evidence from snow pit analysis. Antarctic Science, 18, 497-505. 
Appendix A. Major Ion and Stable Isotope Data

\begin{tabular}{|c|c|c|c|c|c|c|c|c|c|c|}
\hline Location & $\begin{array}{l}\text { Sample date } \\
\text { (dd/mm/yyyy) }\end{array}$ & $\mathrm{Na} \mathrm{mM}$ & $\mathrm{K} \mathrm{mM}$ & $\mathrm{Mg} \mathrm{mM}$ & Ca $\mathrm{mM}$ & $\mathrm{Cl} \mathrm{mM}$ & $\mathrm{SO}_{4} \mathrm{mM}$ & Alk meql ${ }^{-1}$ & Si mM & $\delta^{18} \mathrm{O}$ \\
\hline \multicolumn{11}{|c|}{ Parera Ponds complex } \\
\hline Parera Pond & $07 / 12 / 2001$ & 4.84 & 0.386 & 1.40 & 0.579 & 7.84 & 0.494 & 0.356 & & \\
\hline Parera Pond & $12 / 12 / 2002$ & 1.69 & 0.178 & 0.390 & 0.201 & 2.25 & 0.177 & 0.446 & 0.022 & \\
\hline Parera Pond & $11 / 01 / 2006$ & 86.3 & 4.06 & 56.3 & 13.3 & 225 & 7.03 & & & -18.5 \\
\hline Parera Pond & $30 / 01 / 2008$ & 3.46 & 0.259 & 1.24 & 0.433 & 5.91 & 0.395 & 0.368 & & -20.3 \\
\hline Parera Pond & $13 / 01 / 2009$ & 4.25 & 0.337 & 1.49 & 0.937 & 7.39 & 0.646 & 0.748 & 0.072 & -35.1 \\
\hline Parera Pond & 05/01/2010 & 0.965 & 0.098 & 0.264 & 0.190 & 1.42 & 0.117 & 0.316 & & -21.2 \\
\hline Parera south & $07 / 12 / 2001$ & 61.3 & 3.73 & 20.0 & 9.74 & 104 & 9.92 & 0.476 & & \\
\hline Parera south & $12 / 12 / 2002$ & 1.36 & 0.191 & 0.510 & 0.560 & 2.42 & 0.396 & 0.479 & 0.038 & \\
\hline Parera south & $11 / 01 / 2006$ & 2.82 & 0.398 & 1.32 & 0.756 & 4.98 & 0.880 & 0.628 & & -24.3 \\
\hline Parera south & $30 / 01 / 2008$ & 8.67 & 0.941 & 3.61 & 3.29 & 16.9 & 2.51 & 1.47 & & -15.8 \\
\hline Parera south & $13 / 01 / 2009$ & 1.54 & 0.176 & 0.728 & 1.36 & 4.55 & 0.561 & 0.205 & 0.102 & -24.4 \\
\hline Parera south & $05 / 01 / 2010$ & 20.0 & 1.81 & 7.83 & 2.84 & 36.1 & 2.06 & 2.88 & & -15.5 \\
\hline Parara west & $07 / 12 / 2001$ & 6.60 & 0.494 & 2.20 & 0.780 & 11.6 & 0.789 & & & \\
\hline Parara west & $30 / 01 / 2008$ & 50.9 & 5.80 & 26.2 & 7.88 & 112 & 5.70 & 1.25 & & -23.0 \\
\hline Parara west & $13 / 01 / 2009$ & 51.7 & 6.19 & 25.1 & 8.79 & 113 & 5.83 & 1.13 & 0.108 & -16.5 \\
\hline Parara west & $05 / 01 / 2010$ & 3.62 & 0.447 & 1.59 & 1.69 & 6.88 & 0.895 & 1.94 & & -14.8 \\
\hline \multicolumn{11}{|c|}{ Marr ponds complex } \\
\hline Marr pond 1 & $28 / 01 / 2002$ & 2.06 & 0.159 & 0.730 & 0.490 & 3.61 & 0.204 & 0.637 & & \\
\hline Marr pond 1 & $17 / 01 / 2003$ & 0.370 & 0.047 & 0.120 & 0.120 & 0.570 & 0.037 & 0.253 & 0.039 & \\
\hline Marr pond 1 & $31 / 12 / 2003$ & 0.854 & 0.150 & 0.237 & 0.180 & 1.25 & 0.104 & 0.380 & 0.034 & -17.3 \\
\hline Marr pond 1 & $20 / 01 / 2006$ & 0.630 & 0.073 & 0.218 & 0.261 & 1.01 & 0.149 & 0.349 & 0.053 & -27.4 \\
\hline Marr pond 1 & 19/01/2007 & 0.434 & 0.083 & 0.135 & 0.239 & 0.530 & 0.070 & 0.595 & 0.078 & -9.5 \\
\hline Marr pond 1 & 06/01/2010 & 0.499 & 0.060 & 0.143 & 0.251 & 0.733 & 0.059 & 0.496 & & -27.8 \\
\hline Marr pond 2 & $28 / 01 / 2002$ & 1.82 & 0.150 & 0.650 & 0.480 & 3.23 & 0.196 & 0.608 & & \\
\hline Marr pond 2 & $17 / 01 / 2003$ & 0.650 & 0.088 & 0.230 & 0.250 & 0.960 & 0.093 & 0.552 & 0.097 & \\
\hline Marr pond 2 & $23 / 12 / 2004$ & 0.770 & 0.110 & 0.300 & 0.343 & 1.05 & 0.179 & 0.758 & 0.098 & -28.4 \\
\hline Marr pond 2 & $20 / 01 / 2006$ & 0.705 & 0.088 & 0.290 & 0.285 & 1.10 & 0.132 & 0.577 & 0.103 & -27.0 \\
\hline Marr pond 2 & $19 / 01 / 2007$ & 0.868 & 0.113 & 0.318 & 0.274 & 1.30 & 0.120 & 0.625 & 0.105 & -28.3 \\
\hline Marr pond 2 & $22 / 01 / 2008$ & 0.706 & 0.120 & 0.264 & 0.324 & 0.747 & 0.178 & 0.899 & & -19.5 \\
\hline Marr pond 2 & $06 / 01 / 2010$ & 0.783 & 0.117 & 0.198 & 0.269 & 1.13 & 0.096 & 0.509 & & -27.4 \\
\hline Marr pond 3 & $28 / 01 / 2002$ & 1.84 & 0.159 & 0.700 & 0.540 & 3.29 & 0.219 & 0.751 & & \\
\hline Marr pond 3 & $17 / 01 / 2003$ & 1.51 & 0.171 & 0.470 & 0.360 & 2.17 & 0.238 & 0.695 & 0.100 & \\
\hline Marr pond 3 & $23 / 12 / 2004$ & 1.17 & 0.140 & 0.370 & 0.349 & 1.52 & 0.213 & 0.802 & 0.103 & -27.9 \\
\hline Marr pond 3 & $20 / 01 / 2006$ & 1.23 & 0.140 & 0.441 & 0.388 & 1.77 & 0.243 & 0.770 & 0.105 & -25.2 \\
\hline Marr pond 3 & $19 / 01 / 2007$ & 1.68 & 0.193 & 0.507 & 0.407 & 2.22 & 0.350 & 0.774 & 0.102 & -27.9 \\
\hline Marr pond 3 & $14 / 01 / 2009$ & 0.946 & 0.123 & 0.426 & 0.402 & 1.62 & 0.187 & 0.732 & 0.122 & -26.5 \\
\hline Marr pond 3 & $31 / 12 / 2009$ & 1.78 & 0.188 & 0.445 & 0.364 & 2.55 & 0.312 & 0.417 & & -26.0 \\
\hline Marr pond 3 & $31 / 12 / 2009$ & 1.50 & 0.159 & 0.336 & 0.303 & 2.06 & 0.251 & 0.374 & & -26.6 \\
\hline Marr pond 3 & $06 / 01 / 2010$ & 2.09 & 0.225 & 0.562 & 0.442 & 2.86 & 0.367 & 0.730 & & -25.6 \\
\hline Marr pond 4 & $28 / 01 / 2002$ & 9.57 & 1.10 & 3.56 & 1.14 & 17.0 & 1.06 & 0.943 & & \\
\hline Marr pond 4 & $17 / 01 / 2003$ & 0.920 & 0.128 & 0.350 & 0.160 & 1.56 & 0.140 & 0.228 & 0.024 & \\
\hline Marr pond 4 & $23 / 12 / 2004$ & 1.07 & 0.150 & 0.350 & 0.332 & 1.27 & 0.186 & 0.942 & 0.072 & -26.5 \\
\hline Marr pond 4 & $20 / 01 / 2006$ & 1.96 & 0.224 & 0.729 & 0.386 & 3.05 & 0.341 & 0.686 & 0.123 & -25.3 \\
\hline Marr pond 4 & $19 / 01 / 2007$ & 0.908 & 0.124 & 0.320 & 0.184 & 1.45 & 0.131 & 0.324 & 0.035 & -25.6 \\
\hline Marr pond 4 & $22 / 01 / 2008$ & 0.856 & 0.129 & 0.244 & 0.178 & 1.26 & 0.108 & 0.355 & & -23.1 \\
\hline Marr pond 4 & $31 / 12 / 2009$ & 0.420 & 0.076 & 0.101 & 0.099 & 0.505 & 0.048 & 0.294 & & -24.0 \\
\hline Marr pond 4 & $31 / 12 / 2009$ & 0.474 & 0.102 & 0.114 & 0.111 & 0.580 & 0.052 & 0.342 & & -25.4 \\
\hline Marr pond 4 & $06 / 01 / 2010$ & 0.476 & 0.087 & 0.119 & 0.114 & 0.580 & 0.054 & 0.340 & & -24.1 \\
\hline Marr pond 5 & $17 / 01 / 2003$ & 1.88 & 0.242 & 0.820 & 0.230 & 3.60 & 0.178 & 0.262 & 0.021 & \\
\hline Marr pond 5 & $20 / 01 / 2006$ & 5.11 & 0.443 & 2.67 & 0.687 & 10.4 & 0.610 & 0.585 & 0.035 & -25.8 \\
\hline Marr pond 5 & $06 / 01 / 2010$ & 4.63 & 0.536 & 1.56 & 0.517 & 8.10 & 0.326 & 0.559 & & -25.0 \\
\hline
\end{tabular}




\section{Acience \\ Volume $24 \quad$ Number 12012}

\section{CONTENTS}

Guest Editorial

\section{BIOLOGICAL SCIENCES}

The geochemistry of upland ponds, Taylor Valley, Antarctica

W. Berry Lyons, KathleEn A. Welch,

Christopher B. Gardner, Chris Jaros,

Daryl L. Moorhead, Jennifer L. KnOEPfle

\& Peter T. Doran

Density, body size and sex ratio of an indigenous spider along an altitudinal gradient in the sub-Antarctic Jennifer E. Lee, Michael J. Somers \& Steven L. Chown

Chemical limnology in coastal East Antarctic lakes: monitoring future climate change in centres of endemism and biodiversity

Elie Verleyen, Dominic A. Hodgson, John Gibson, Satoshi ImURa, EnN Kaup, SaKaE Kudoh,

Aaike De Wever, Tamotsu Hoshino, Andrew McMinn, Dagmar Obbels, Donna Roberts, Steve Roberts, Koen Sabbe, Caroline Souffreau, Ines Tavernier, Wim Van NieuWEnHUyze, ERIC VAN RANST, Nicole VindeVOGel \& Wim VyVERman

Mercury concentrations of two toothfish and three of its prey species from the Pacific sector of the Antarctic Stuart M. Hanchet, Dianne Tracey, Alistair Dunn, Peter Horn \& Neville Smith

Short Note: Critical thermal minima of three sub-Antarctic insects from the French southern Indian Ocean islands D. Renault \& L. Lalouette

\section{EARTH SCIENCES}

Magnetic fabric and tectonic setting of the Early to Middle Jurassic felsic dykes at Pitt Point and Mount Reece, eastern Graham Land, Antarctica JIŘi ŽÁK, IGOR SOEJONO, VOJTĚCH JANOUŠEK \& ZDENĚK VENERA

Influence of the Antarctic Oscillation, the Pacific-South American modes and the EI Niño-Southern Oscillation on the Antarctic surface temperature and pressure variations

Lejiang Yu, Zhanhai Zhang, Mingyu Zhou,

15 Sharon Zhong, Donald Lenschow, HsiaOming Hsu, Huiding Wu \& Bo Sun

Shape and size of Antarctic icebergs derived from ship observation data

Yuri A. Romanov, Nina A. Romanova

\& Peter Romanov

\section{PHYSICAL SCIENCES}

Automatic scaling of polar ionograms Carlo Scotto \& Michael Pezzopane

Blue ice areas and their topographical properties in the Lambert glacier, Amery Iceshelf system using Landsat ETM+, ICESat laser altimetry

34 and ASTER GDEM data JAEHyUNG Yu, HongXing LiU, Lei Wang, Kenneth C. JezeK \& JoOnghyeok HeO

Book Reviews

Antarctic Science is abstracted in Current Contents, SciSearch, Research Alert, Geo Abstracts, Current Awareness in Biological Sciences, Mineralogical Abstracts, Meteorological \& Geo-astrophysical Abstracts, Current Antarctic Literature, GeoArchive, GeoRef, Biosis, Oceanographic Literature, Environmental Periodicals Bibliography and Polar \& Glaciological Abstracts

Cambridge Journals Online For further information about this journal please go to the journal website at: journals.cambridge.org/ans
MIX

Paper from responsible sources $\mathrm{FSC}^{\curvearrowright} \mathrm{C} 018127$
CAMBRIDGE
UNIVERSITY PRESS 